\title{
Potensi Bayam Merah (Amaranthus tricolor $L$ ) sebagai Antioksidan pada Toksisitas Timbal yang Diinduksi pada Mencit
}

\author{
Sundari Indah Wiyasihati, Kristanti Wanito Wigati \\ Departemen Ilmu Faal Fakultas Kedokteran Universitas Airlangga Surabaya
}

\begin{abstract}
Abstrak
Seiring dengan peningkatan industrialisasi dan transportasi, polusi logam berat yang ditimbulkan pun semakin meningkat. Timbal merupakan toksin yang paling bermakna di antara logam berat lain yang memiliki kecenderungan untuk mengkatalisis reaksi oksidasi dan menimbulkan terbentuknya Reactive Oxygen Species (ROS). Bayam merah (Amaranthus tricolor L) mengandung komponen antioksidan yang berpotensi menurunkan kadar timbal dalam darah dan mencegah toksisitasnya. Penelitian dilaksanakan di Laboratorium Biokimia Fakultas Kedokteran Universitas Airlangga selama bulan Agustus-September 2012. Penelitian eksperimental laboratoris ini menggunakan posttest only control group design. Tiga puluh ekor mencit dibagi menjadi tiga kelompok: $\mathrm{K}_{0}$ sebagai kelompok kontrol yang diberikan akuades dan plasebo, $\mathrm{K}_{1}$ sebagai kelompok perlakuan yang diberikan timbal asetat $0,75 \mathrm{mg} / 10 \mathrm{gBB}$ dan plasebo, $\mathrm{K}_{2}$ sebagai kelompok perlakuan yang diberikan timbal asetat $0,75 \mathrm{mg} / 10 \mathrm{gBB}$ dan 382,2 mg/10 gBB jus bayam merah selama 28 hari. Darah diambil dari vena ekor tikus untuk pemeriksaan superoxide dismutase (SOD) dan malondialdehyde (MDA). Hasil pemeriksaan kadar SOD rata-rata darah mencit pada $\mathrm{K} 0(\mathrm{n}=10) 55,91 \pm 9,61 \%$, $\mathrm{K} 1(\mathrm{n}=10) 31,29 \pm 12,87 \%$, dan $\mathrm{K} 2(\mathrm{n}=10) 34,83 \pm 10,12 \%$ $(\mathrm{p}=0,000)$. Nilai kadar MDA rata-rata darah mencit pada K0 9,9 nmol/mL, K1 12,04 nmol/mL, dan K2 11,05 $\mathrm{nmol} / \mathrm{mL}(\mathrm{p}=0,002)$. Berdasarkan uji ANOVA, disimpulkan bahwa bayam merah dapat meningkatkan SOD dan menurunkan MDA plasma pada toksisitas yang diinduksi timbal asetat pada mencit. [MKB. 2016;48(2):63-7]
\end{abstract}

Kata kunci: Amaranthus tricolor linn, antioksidan, bayam merah, toksisitas timbal

\section{The Potency of Red Spinach (Amaranthus tricolor $L$ ) as an Antioxidant for Lead-Induced Toxicities in Mice}

\begin{abstract}
Along with the increasing industrialization and transportation, the generated heavy metal pollution is increasing. Lead is the most significant toxin among heavy metals and has a tendency to catalyze the oxidation reaction and lead to the formation of Reactive Oxygen Species (ROS). Red spinach (Amaranthus tricolor $L$ ) contains antioxidant properties which have a potential to reduce the blood lead level and prevent the lead-induced toxicities. The study was conducted at the Laboratory of Biochemistry Faculty of Medicine, Universitas Airlangga, during AugustSeptember 2012. This laboratory experimental study used pos-ttest only control group design. Thirty mice were divided into 3 groups: $\mathrm{K} 0$ as the control group with aquadest and placebo; $\mathrm{K} 1$ as the treatment group with lead acetate $0.75 \mathrm{mg} / 10 \mathrm{gBW}$ and placebo treatment; and $\mathrm{K} 2$ as the treatment group with lead acetate $0.75 \mathrm{mg} / 10$ gBW and $382.2 \mathrm{mg} / 10 \mathrm{gBW}$ red spinach juice treatment for 28 days. Blood was drawn from the mouse's tail vein for examination of superoxide dismutase (SOD) and malondialdehyde (MDA). Mean blood SOD value in K0 ( $n=10)$ was $55.91 \pm 9.61 \%, \mathrm{~K} 1(\mathrm{n}=10)$ was $31.29 \pm 12.87 \%$, and $\mathrm{K} 2(\mathrm{n}=10)$ was $34.83 \pm 10.12 \%(\mathrm{p}=0.000)$. Mean blood MDA value for $\mathrm{K} 0$ was $9.9 \mathrm{nmol} / \mathrm{mL}$, K1 was $12.04 \mathrm{nmol} / \mathrm{mL}$, and $\mathrm{K} 2$ was $11.05 \mathrm{nmol} / \mathrm{mL}(\mathrm{p}=0.002)$. Based on ANOVA test, it is concluded that the administration of red spinach can increase SOD and decrease MDA plasma on lead-induced toxicity in mice. [MKB. 2016;48(2):63-7]
\end{abstract}

Key words: Amaranthus tricolor linn, antioxidant, lead-induced toxicities, red spinach

Korespondensi: Sundari Indah Wiyasihati, dr., MSi, Departemen Ilmu Faal, Fakultas Kedokteran, Universitas Airlangga Surabaya, Jalan Prof. Dr. Moestopo No. 8A Surabaya, mobile 08123228503, e-mail sundari-i-w@fk.unair.ac.id 


\section{Pendahuluan}

Seiring terdapatnya peningkatan industrialisasi dan transportasi, polusi logam berat yang ditimbulkan seperti timbal $(\mathrm{Pb})$, seng $(\mathrm{Zn})$, air raksa $(\mathrm{Hg})$, tembaga $(\mathrm{Cu})$, besi $(\mathrm{Fe})$, dan sebagainya semakin pula meningkat. Timbal merupakan toksin yang paling bermakna ${ }^{1}$ dan toksisitasnya bergantung pada besar dosis dan lama paparan. ${ }^{2}$ Timbal banyak dihasilkan oleh pabrik baterai, pabrik peleburan logam, industri tembikar, kaleng makanan, mesin percetakan, dan gas buang kendaraan bermotor, ${ }^{3,4}$

Timbal mempunyai kecenderungan untuk mengkatalisis reaksi oksidasi dan menimbulkan terbentuknya reactive oxygen species (ROS). ROS dapat menghambat produksi antioksidan sulfhidril,menghambatenzimyangmemproduksi heme, merusak asam nukleat, dan menghambat perbaikan DNA. ROS juga menyebabkan reaksi peroksidasi lipid pada membran sel. ${ }^{5}$ Paparan timbal akan mengakibatkan biomarker stres oksidatif malondialdehid (MDA) meningkat di atas rata-rata populasi kontrol dan menyebabkan kadar GSH, glutation peroksidase, dan katalase menurun. ${ }^{2}$

Negara beriklim tropis kaya akan tanaman yang berkhasiat bagi kesehatan manusia. Salah satunya adalah bayam merah atau Amaranthus tricolor $L$ yang memiliki kandungan komponen antioksidan; ${ }^{6}$ antara lain betalain, karotenoid, vitamin C, flavanoid, dan polifenol. ${ }^{7}$ Potensi antioksidan bayam merah diketahui telah jauh melampaui seledri dan daun rosella. ${ }^{8}$ Komponen antioksidan mempunyai potensi menurunkan kadar timbal di dalam darah sehingga mampu mencegah efek toksisitasnya. Selain itu, bayam merah juga diketahuikayaakan serat dan berbagai mineral yang dapat menurunkan absorbsi timbal di saluran cerna dan meningkatkan ekskresinya. Masyarakat pada umumnya memasak bayam merah terlebih dahulu untuk konsumsi sehingga menyebabkan hilangnya senyawa-senyawa yang bersifat antioksidan. Penelitian ini bertujuan menguji efektivitas jus bayam merah sebagai antioksidan herbal secara in vitro pada mencit yang dipapar timbal asetat secara oral.

\section{Metode}

Penelitian eksperimental laboratoris dilakukan secara in vitro dengan menggunakan rancangan randomized posttest only control group design. Hewan coba yang digunakan adalah mencit (Mus musculus) sebanyak 30 ekor berkelamin jantan, berumur 2-4 bulan, bobot badan 20-40 gram, dan kondisi sehat fisik. Aklimatisasi dilakukan selama satu minggu, kemudian dibagi secara acak ke dalam 3 kelompok, yaitu $\mathrm{K}_{0}$ : kelompok kontrol dengan pemberian akuades (pelarut timbal asetat) 0,1 mL/10 gBB 1x/hari dan plasebo (pelarut bayam merah) $0,1 \mathrm{~mL}$ CMC Na 0,5\%/10 gBB 1x/hari; $K_{1}$ : kelompok dengan pemberian timbal asetat $0,75 \mathrm{mg} / 10 \mathrm{gBB} /$ hari sebanyak 0,1 mL/10 gBB 1x/hari + plasebo 0,1 $\mathrm{ml} \mathrm{CMC} \mathrm{Na} \mathrm{0,5 \% /10} \mathrm{gBB} \mathrm{1x/hari;} \mathrm{K}_{2}$ : kelompok dengan pemberian timbal asetat $0,75 \mathrm{mg} / 10$ $\mathrm{gBB} /$ hari sebanyak $0,1 \mathrm{~mL} / 10 \mathrm{gBB} 1 \mathrm{x} /$ hari + jus bayam merah 382,2 mg/10 gBB/hari sebanyak $0,1 \mathrm{~mL} / 10 \mathrm{gBB} 1 \mathrm{x} / \mathrm{hari}$.

Semua hewan coba diinduksi per oral dengan galvage selama 28 hari. ${ }^{9}$ Dosis jus bayam merah yang digunakan setara dengan dosis trolox (analog vitamin E larut air) untuk mendapatkan kapasitas antioksidan sebesar 3,7 mmol untuk manusia dewasa seberat 294 gram $^{10}$ dan juga dikonversikan untuk mencit. Setelah 28 hari pemberian, sampel darah mencit percobaan diambil sebanyak $2 \mathrm{~mL}$ melalui vena ekor. Darah yang diambil kemudian dimasukkan ke dalam tabung reaksi, lalu dipusingkan (centrifuge) untuk mendapatkan plasma yang digunakan untuk pemeriksaan SOD dan MDA menggunakan spektrofotometer.

Penelitian ini dilaksanakan di Laboratorium Biokimia Fakultas Kedokteran Universitas Airlangga selama periode Agustus-September 2012 serta sudah mendapatkan keterangan kelaikan etik dari Komite Etik Kesehatan Fakultas Kedokteran Universitas Airlangga (No. 037/EC/ KEPK/FKUA/2012). Data telah yang diperoleh ditabulasi dan dianalisis secara statistik melalui tahapan uji deskriptif, uji normalitas distribusi data, uji ANOVA untuk mengetahui perbedaan antarkelompok perlakuan, dan uji beda lanjutan menggunakan LSD.

\section{Hasil}

MDA rata-rata (Gambar 1) pada kelompok mencit yang diberi timbal asetat tanpa bayam merah $\left(\mathrm{K}_{1}\right.$ : timbal asetat $0,75 \mathrm{mg} / 10 \mathrm{gBB} /$ hari) mengalami peningkatan bila dibanding dengan kelompok mencit kontrol tanpa pemberian timbal asetat dan bayam merah $\left(\mathrm{K}_{0}\right.$ : : plasebo) serta mengalami penurunan pada kelompok mencit yang diinduksi timbal asetat kemudian diberikan jus bayam merah $\left(\mathrm{K}_{2}\right)$ : timbal asetat $0,75 \mathrm{mg} / 10 \mathrm{gBB} / \mathrm{hari}+$ jus bayam merah 382,2 $\mathrm{mg} / 10 \mathrm{gBB} /$ hari). Hal ini memperlihatkan hasil 


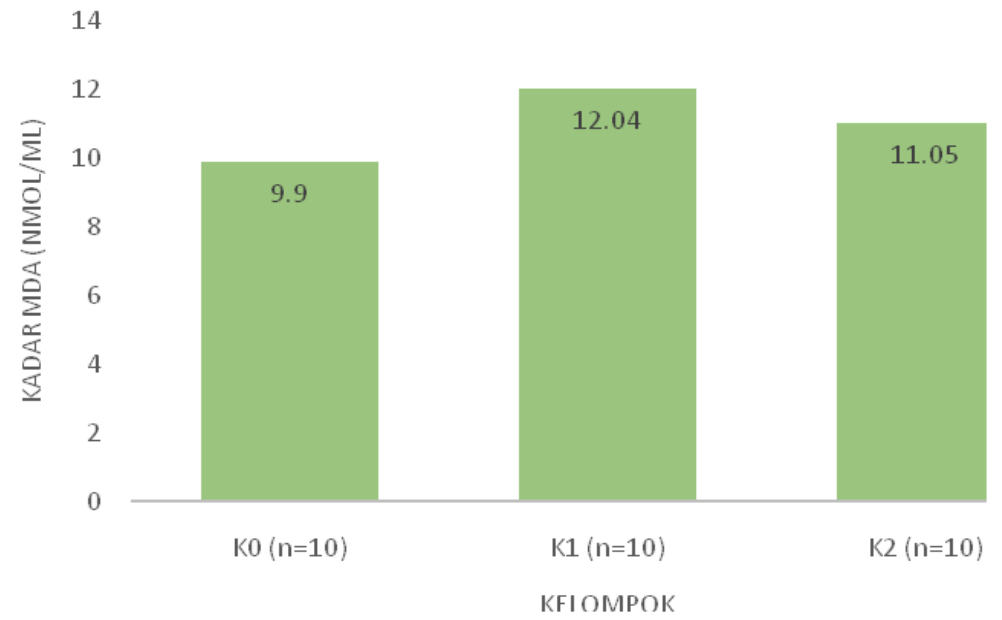

Gambar 1 Nilai Kadar MDA Rata-rata (nmol/mL) Darah Mencit

K0 (kontrol) diinduksi akuades + plasebo, K1 diinduksi timbal asetat 0,075 g/kgBB + plasebo, K2 diinduksi timbal asetat $0,075 \mathrm{~g} / \mathrm{kgBB}+382 \mathrm{~g} / \mathrm{kgBB}$ jus bayam merah.

bahwa dosis timbal asetat yang diberikan sudah menyebabkan kerusakan sel pada mencit dan pemberian jus bayam merah dapat memperbaiki kerusakan yang disebabkan oleh pemberian timbal asetat.

Sebaliknya, kadar SOD rata-rata (Gambar 2) pada kelompok mencit yang diinduksi dengan timbal asetat tanpa pemberian jus bayam merah $\left(\mathrm{K}_{1}\right)$ mengalami penurunan apabila dibanding dengan tikus kontrol tanpa induksi timbal asetat dan pemberian jus bayam merah $\left(\mathrm{K}_{0}\right)$ dan mengalami peningkatan pada kelompok mencit yang diinduksi dengan timbal asetat lalu diberikan jus bayam merah $\left(\mathrm{K}_{2}\right)$. Keadaan ini menunjukkan bahwa dosis timbal yang diberikan telah menurunkan aktivitas SOD dan pemberian jus bayam merah dapat memperbaiki kerusakan yang ditimbulkan oleh timbal asetat.

Data yang diperoleh berdistribusi secara normal sehingga dilakukan uji analisis varians (ANOVA) yang menunjukkan perbedaan yang bermakna (kadar MDA $\mathrm{p}=0,002$ dan kadar SOD $\mathrm{p}=0,000$ ) sehingga dilanjutkan dengan uji LSD untuk variasi antarkelompok homogen. Hasil uji LSD untuk kadar MDA menunjukkan penurunan yang bermakna antara setiap kelompok hewan coba $(p<0,005)$. Hasil uji LSD untuk kadar SOD antara kelompok mencit yang diinduksi dengan

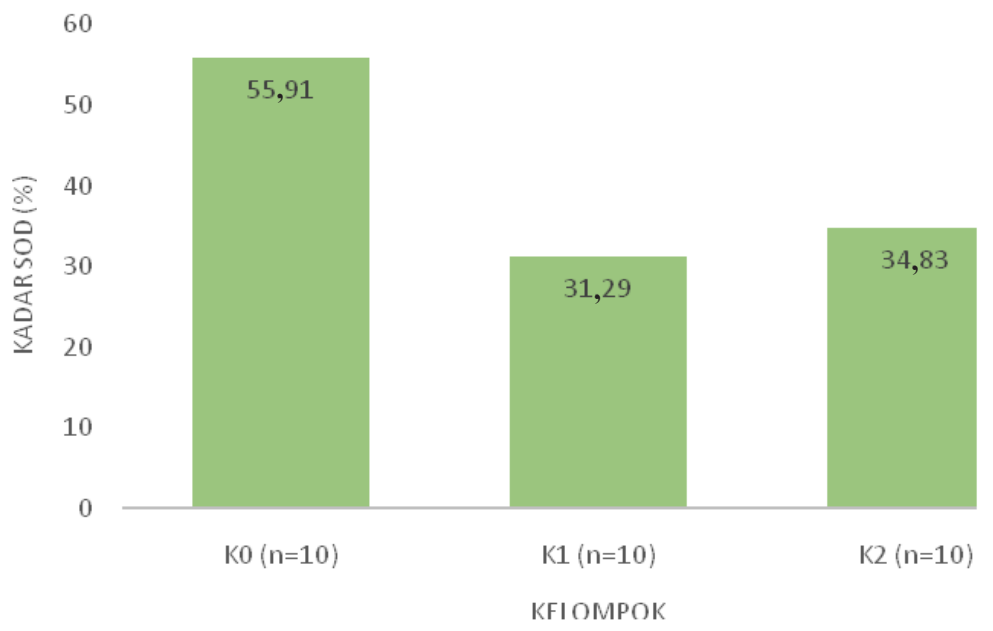

Gambar 2 Nilai Kadar SOD Rata-rata (\%) Darah Mencit

K0 (kontrol) diinduksi akuades + plasebo, K1 diinduksi timbal asetat 0,075 g/kgBB + plasebo, K2 diinduksi timbal asetat $0,075 \mathrm{~g} / \mathrm{kgBB}+382 \mathrm{~g} / \mathrm{kgBB}$ jus bayam merah. 
timbal asetat tanpa pemberian jus bayam merah $\left(\mathrm{K}_{1}\right)$ dan mencit yang diinduksi dengan timbal asetat kemudian diberikan jus bayam merah $\left(\mathrm{K}_{2}\right)$ memperlihatkan peningkatan SOD secara tidak bermakna dengan nilai $p=0,476$. Akan tetapi, terdapat peningkatan SOD yang sangat bermakna antara mencit kontrol $\left(\mathrm{K}_{0}\right)$ dan mencit yang diberi timbal asetat kemudian diberikan jus bayam merah $\left(\mathrm{K}_{2}\right)$.

\section{Pembahasan}

Timbal merupakan toksin lingkungan yang bersifat persisten yang dapat mengakibatkan gangguan padaorgan saraf, darah, gastrointestinal, reproduksi, sirkulasi, dan imunologi. Mekanisme gangguan yang disebabkan oleh paparan logam berat pada umumnya adalah sama, yaitu melalui kerusakan oksidatif. ${ }^{5}$

Toksisitas timbal menyebabkan kerusakan radikal melalui 2 jalur, yaitu melalui pembentukan ROS, seperti hidroperoksida, oksigen singlet dan oksigen peroksida, serta melalui penurunan cadangan antioksidan. ${ }^{5}$ Pada sistem biologis, produksi ROS yang meningkat akan diikuti oleh penurunan cadangan antioksidan. Penurunan aktivitas enzim-enzim antioksidan dan glutation ini terjadi karena timbal mampu berinteraksi dengan gugus sulfhidril atau kofaktor logam pada enzim dan molekul tersebut. Golongan enzim yang mempunyai gugus prostetik logam mungkin dapat digantikan oleh timbal sehingga menghambat aktivitas enzim tersebut. SOD merupakan salah satu jenis enzim ini.

Reactive oxygen species akan menyebabkan peroksidasi lipid, kerusakan DNA, dan juga penurunan pada sistem pertahanan antioksidan dalam sel. ${ }^{11}$ Penelitian pada kelinci yang dipapar timbal asetat menunjukkan peningkatan lipid peroksidase (LPO) serum yang menyebabkan kerusakan asam lemak tidak jenuh ganda penyusun fosfolipid membran sel. ${ }^{12}$ Produk akhir akibat reaksi peroksidasi lipid ini adalah MDA. Hal ini sesuai dengan hasil penelitian (Gambar 1) bahwa kadar MDA pada mencit yang diberi timbal asetat tanpa diikuti dengan pemberian jus bayam merah $\left(\mathrm{K}_{1}\right)$ lebih tinggi dibanding dengan mencit kontrol tanpa diberi timbal asetat $\left(\mathrm{K}_{0}\right)$ yang menunjukkan bahwa timbal asetat mengakibatkan kerusakan oksidatif pada sel mencit. SOD pada kelompok mencit yang diberi timbal asetat tanpa diikuti dengan pemberian jus bayam merah $\left(\mathrm{K}_{1}\right)$ lebih rendah dibanding dengan kelompok mencit kontrol $\left(\mathrm{K}_{0}\right)$ (Gambar 2). Hasil ini menunjukkan bahwa timbal asetat menyebabkan penurunan simpanan antioksidan alami tubuh.

Bayam merah memiliki kandungan flavonoid, betalain, vitamin $\mathrm{C}$, dan juga vitamin A yang merupakan antioksidan yang poten. ${ }^{6,7}$ Bayam merah juga kaya mineral, piridoksin, riboflavin..$^{13}$ serta asam folat dalam jumlah yang banyak. ${ }^{14}$ Antioksidan tersebut dapat memperbaiki efek penghambatan timbal pada antioksidan alami tubuh dengan cara membersihkan ROS segera sesudah terbentuk sehingga reaksi radikal berantai tersebut akan tidak terjadi. Kandungan mineral pada bayam merah juga berfungsi untuk mencegah kerusakan antioksidan alami tubuh akibat logam transisional. Diet tinggi serat, $\mathrm{Fe}$, Ca, Zinc, dan fosfor yang dikandung bayam merah (Amaranthus tricolor Linn) diduga dapat menurunkan absorpsi timbal di dalam saluran cerna sehingga menurunkan kadar timbal di dalam darah. Mekanisme kerjanya diduga melalui competitive inhibitor antara $\mathrm{Fe}, \mathrm{Ca}$, Zinc, dan fosfor dengan timbal pada berbagai binding site di membran sel ataupun di dalam sel. ${ }^{15}$ Betalain dan vitamin $C$ selain sebagai antioksidan, juga diduga memiliki kemampuan sebagai chelator melalui kemampuannya membentuk kompleks ion yang larut air dan juga mampu membentuk kompleks dengan logam sehingga kemungkinan kadar timbal darah dan jaringan juga dapat diturunkan melalui mekanisme tersebut. ${ }^{16-18}$ Vitamin C diketahui dapat menghambat ambilan timbal di tingkat seluler dan juga menghambat sitotoksisitas timbal. ${ }^{19}$ Hal ini tampak dalam hasil yang diperoleh dalam penelitian ini bahwa kadar SOD kelompok mencit yang diberikan timbal asetat tanpa jus bayam merah $\left(\mathrm{K}_{1}\right)$ lebih rendah dibanding dengan kelompok mencit yang diberikan timbal asetat kemudian diberikan jus bayam merah $\left(\mathrm{K}_{2}\right)$. Dengan demikian, dapat disimpulkan bahwa pemberian jus bayam merah mampu memperbaiki status antioksidan alami tubuh. Antioksidan yang meningkat juga mencegah kerusakan sel akibat radikal bebas. Hal ini ditunjukkan dengan hasil penelitian bahwa nilai MDA kelompok mencit yang diberikan timbal asetat tanpa diikuti dengan pemberian jus bayam merah $\left(K_{1}\right)$ lebih tinggi dibanding dengan kelompok mencit yang diberikan timbal asetat kemudian diberikan jus bayam merah $\left(\mathrm{K}_{2}\right)$.

Simpulan, pemberian jus bayam merah (Amaranthus tricolor Linn) dapat meningkatkan SOD dan juga menurunkan MDA mencit (Mus musculus) yang dipapar timbal asetat. Hal ini menunjukkan bayam merah memiliki potensi antioksidan yang kuat untuk melindungi sel dari kerusakan akibat radikal bebas. Perlu 
diadakan penelitian lanjutan untuk mengetahui dosis optimal pemberian jus bayam merah dan mekanismenya sebagai antioksidan herbal.

\section{Ucapan Terima Kasih}

Penelitian ini didanai oleh hibah riset Fakultas Kedokteran Universitas Airlangga.

\section{Daftar Pustaka}

1. Duruibe JO, Ogwuegbu MOC, Egwurugwu JN. Heavy metal pollution and human biotoxic effects. Int J Phys Sci. 2007;2(5):112-8.

2. Verstraeten SV, Aimo L, Oteiza PI. Aluminium and lead: molecular mechanism of brain toxicity. Arch Toxicol. 2008;82(11):789-802.

3. Chowdhury AR. Recent advances in heavy metals induced effect on male reproductive function-a retrospective. Al Ameen J Med Sci. 2009;2(2):37-42.

4. WHO. Lead in drinking-water. Background document for development of WHO Guidelines for drinking-water quality. Geneva: WHO; 2011.

5. Patrick L. Lead toxicity part ii: the role of free radical damage and the use of antioxidants in the pathology and treatment of lead toxicity. Altern Med Rev. 2006;11(2):114-27.

6. Amin I, Norazaidah Y, Emmy Hainida KI. Antioxidant activity and phenolic content of raw and blanched Amaranthus species. Food Chem. 2006;94(1):47-52.

7. Khanam UKS. Morphological properties and bioactive constituents of amaranth, Amaranthus tricolor L. Presentasi oral pada $9^{\text {th }}$ International Food Data Conferences (IFDC) 2011 September 14-17. Norwich.

8. Wong SP, Leong LP, Koh JHW. Antioxidant activities of aqueous extracts of selected plants. Food Chem. 2006;99(4):775-83.

9. Widarti L. Pengaruh pemberian larutan timbal asetat terhadap berat dan folikulogenesis pada ovarium mencit (Mus Musculus) [tesis]. Surabaya: Universitas Airlangga; 2006.

10. Cao G, Russel RM, Lischner N, Prior RL. Serum antioxidant capacity is increased by consumption of strawberries, spinach, red wine or vitamin $\mathrm{C}$ in elderly women. J Nutr. 1998;128(12):2383-90.

11. Gurer H, Ercal N. Can antioxidants be beneficial in the treatment of lead poisoning? Free Radic Biol Med. 2000;29:927-45.

12. El-Tohamy MM, El-Nattat WS. Effect of antioxidant on lead-induced oxidative damage and reproductive dysfunction in male rabbits. J Am Sci. 2010;6(11):613-22.

13. Rajalakshmi K, Haribabu TE, Sudha PN. Toxicokinetic studies of antioxidants of amaranthus tricolour and marigold (Calendula oficinalis L.) plants exposed to heavy metal lead. IJPAES. 2011;1(2):105-9.

14. Verma RJ, Sisodia R, Bhatia AL. Amaranthus gangeticus protects mice brain against radiation induced free radical damage. J Med Phys. 2002;27(3):133-4.

15. Center for Disease Control and Prevention. Toxicology profile of lead. USA: Public Health Service, US Departement of Health and Human Service. 2007.

16. Butera D, Tesoriere L, Di Gaudio F, Bongiorno A, Allegra M, Pintaudi AM, dkk. Antioxidant activities of sicilian prickly pear (Opuntia ficus indica) fruit extracts and reducing properties of its betalains: betanin and indicaxanthin. J Agric Food Chem. 2002; 5(23):6895-901.

17. Flora SJS, Pachauri V. Chelation in metal intoxication. Int J Environ Res Public Health. 2010;7(7):2745-88.

18. Gazdik Z, Zitka O, Petrlova J. Determination of vitamin C (ascorbic acid) using high performance liquid chromato-graphy coupled with electrochemical detection. Sensors. 2008;8(11):7097-112.

19. Taylor RJ, O'Brien E. Nutrition to fight lead poisoning. LEAD Action News. 2010;10(2):110. 